\title{
ANALISIS PENGAMBILAN KEPUTUSAN PETANI: KASUS PERALIHAN USAHATANI PADI KE USAHATANI IKAN DI DESA BUNKATE KECAMATAN JONGGAT KABUPATEN LOMBOK TENGAH
}

\author{
Analysis of Farmers Decision Making: Transtion Case of Rice Farming \\ to Fish Farming in Bunkate Village Jonggat Sub-District \\ Of Central Lombok Regency \\ By: \\ Yupi Ratnasari \\ NIM. C1G013248
}

Main Supervisor: Dr. Ir. Abdullah Usman, M.Agr.Sc., and Supervisor I: Dr. Ir. M. Siddik, MS.

\begin{abstract}
ABSTRAK
Penelitian ini bertujuan menganalisis faktor-faktor yang mempengaruhi keputusan petani dalam melakukan peralihan usahatani padi ke usahatani ikan, menggunakan metode deskriptif dengan pengumpulan data yang digunakan adalah teknik survei dan wawancara. Unit analisis penelitian ini adalah petani padi dan petani ikan di desa Bunkate. Penelitian ini dilakukan di Desa Bunkate, berdasarkan data petani ikan terbesar di Kecamatan Jonggat. Jumlah responden ditetapkan secara "Quota Sampling" sebanyak 44 orang, 22 orang petani padi dan 22 orang petani ikan. Analisis data yang digunakan adalah: analisis regresi logistik dan analisis uji t. Hasil penelitian menunjukkan bahwa faktor yang mempengaruhi peralihan usahatani padi ke usahatani ikan adalah pendapatan. Hal ini disebabkan oleh pendapatan usahatani ikan yaitu Rp. 122.752.923/ha lebih besar dibandingkan dengan pendapatan usahatani padi Rp. 13.183.734/ha. Modal, luas lahan, jumlah tanggungan keluarga dan resiko usahatani tidak berpengaruh nyata terhadap pengambilan keputusan petani melakukan peralihan usahatani. Nilai $\mathrm{R} / \mathrm{C}$ ratio pada usahatani padi lebih kecil dibandingkan dengan usahatani ikan. Hal ini desabkan oleh produksi dan harga produk pada usahatani ikan lebih besar dibandingkan dengan produksi dan harga produk pada usahatani padi.
\end{abstract}

Kata kunci: peralihan usahatani, usahatani padi, usahatani ikan.

ABSTRACT 
The purpose of this research is to analyze the factors that influence the decision of farmers in making the transition of rice farming to fish farming. This research uses descriptive method and data collection technique used is survey and interview technique. The unit of analysis of this research is rice farmers and fish farmers in Bunkate village. This research was conducted in Bunkate Village, based on the data of the biggest fish farmer in Jonggat District. The number of respondents is determined by "Quota Sampling" as many as 44 people, 22 rice farmers and 22 fish farmers. Data analysis used were: analysis of factors influencing rice farming transition to fish farming, and income comparison analysis between rice farming and fish farming. The results showed that the factors affecting the shift of rice farming to fish farming were income. This is caused by the income of fish farming is Rp. 122.752.923 / ha greater than the income of rice farming Rp. 13,183,734 / ha. Capital, land area, number of family dependent and farming risk have no significant effect to farmer's decision making to make farming transition. The value of $\mathrm{R} / \mathrm{C}$ ratio in rice farming is smaller than fish farming. This is explained by the production and price of products in fish farming is greater than the production and price of products in rice farming.

Keyword: farm transition, rice farming, fish farming.

\section{PENDAHULUAN}

\subsection{Latar Belakang}

Indonesia merupakan negara agraris dimana terdapat kekayaan alam yang melimpah dan masyarakat yang didominasi oleh petani yang bergantung hidup pada sektor pertanian. Sektor pertanian dianggap mampu meningkatkan pendapatan dan devisa negara melalui ekspor. Selain itu sektor pertanian juga berperan penting dalam penyediaan bahan pangan, sebagai bahan industri, menciptakan lapangan kerja dan meningkatkan pendapatan petani. Subsektor secara umum terdiri dari beberapa subsektor yaitu tanaman pangan, perikanan, hortikultura dan perkebunan.

Kecamatan Jonggat merupakan salah satu daerah yang memiliki banyak potensi alam yang mampu dikembangkan, salah satunya adalah sektor pertanian. Kecamatan Jonggat pada tahun 2015, menduduki tempat pertama dengan lahan sawah tanaman padi terluas di Kabupaten Lombok Tengah. Produksi padi di Kecamatan Jonggat pada tahun 2015 sebesar 60.426 ton dari luas panen 9.707 ha dengan rata-rata produktivitas $62,25 \mathrm{kw} / \mathrm{ha}$. Selain padi, Kecamatan Jonggat juga memiliki jumlah petani budidaya perikanan kolam terbesar di Kabupaten Lombok 
Tengah yaitu 565 anggota rumah tangga dengan produksi 11.145 ton (BPS Kabupaten Lombok Tengah, 2017).

\subsection{Rumusan Masalah}

Di Kecamatan Jonggat, Desa Bunkate merupakan salah satu Desa penyumbang terbesar dari total produksi padi dan perikanan di Kabupaten Lombok Tengah. Luas tanam padi di Kecamatan Jonggat tahun 2012 - 2015 cenderung menurun, pada tahun 2012 luas panen padi sebesar 11.225 ha, sedangkan pada tahun 2015 seluas 9.707 ha. Menurut informasi serta berdasarkan pra survey bahwa penurunan luas lahan tanaman padi di Kecamatan Jonggat disebabkan petani padi mulai mengganti lahan padi menjadi kolam usaha ikan (Mina Padi). Konidsi ini akan mengancam keberlangsungan tanaman padi dimasa yang akan datang.

Berdasarkan rumusan tersebut, permasalahan yang dibahas dalam penelitian ini adalah:

1) Faktor-faktor apa sajakah yang mempengaruhi keputusan petani melakukan peralihan usahatani padi ke usahatani ikan di Desa Bunkate Kecamatan Jonggat Kabupaten Lombok Tengah?

2) Berapakah perbandingan pendapatan antara usahatani padi dengan usahatani ikan di Desa Bunkate Kecamatan Jonggat Kabupaten Lombok Tengah?.

\subsection{Tujuan dan Kegunaan Penelitian}

\subsubsection{Tujuan Penelitian}

1) Menganalisis faktor-faktor apa sajakah yang mempengaruhi keputusan petani melakukan peralihan usahatani padi ke usahatani ikan di Desa Bunkate Kecamatan Jonggat Kabupaten Lombok Tengah?

2) Menganalisis perbandingan pendapatan antara usahatani padi dengan usahatani ikan di Desa Bunkate Kecamatan Jonggat Kabupaten Lombok Tengah?

\subsubsection{Kegunaan Penelitian}

1) Sebagai bahan referensi dalam Ilmu Ekenomi khususnya Ekonomi Pertanian.

2) Sebagai bahan referensi dan bacaan yang dapat menambah ilmu pengetahuan bagi pembaca khusunya dalam hal analisis pengambilan keputusan petani.

3) Penelitian ini diharapkan dapat memberikan informasi bagi penyelenggara usahatani dalam rangka meningkatkan pendapatan petani.

4) Diharapkan penelitian ini dapat dijadikan pertimbangan bagi pemerintah daerah setempat dalam rangka perencanaan di bidang pertanian khususnya usahatani padi dan usahatani ikan. 
5) Diharapkan dapat memberikan informasi kepada semua pihak yang berkepentingan dalam penelitian ini.

\subsection{Hipotesis Penelitian}

1) Diduga faktor pendapatan, modal, luas lahan, jumlah tanggungan dan resiko usahatani menyebabkan dilakukannya peralihan usahatani padi ke usahatani ikan.

2) Diduga pendapatan usahatani ikan lebih besar dibandingkan pendapatan usahatani padi.

\section{TINJAUAN PUSTAKA}

\subsection{Dasar Teori}

\subsubsection{Pengertian Usahatani}

Ilmu usahatani biasanya diartikan sebagai ilmu yang mempelajari bagaimana seseorang mengalokasikan sumberdaya yang ada secara efektif dan efisien untuk tujuan memperoleh keuntungan tertinggi pada waktu tertentu. Dikatakan efektif apabila petani atau resoponden dapat mengalokasikan sumberdaya yang mereka miliki (yang dikuasai) sebaik-baiknya, dan dikatakan efisien apabila pemanfaatan sumberdaya tersebut menghasilkan keluaran (output) yang melebihi masukan (input) (Soekartawi, 2006).

\subsubsection{Biaya Usahatani}

Menurut Soekartawi (2006), biaya usahatani diklasifikasikan menjadi dua, yaitu biaya tetap (Fixed Cost) dan biaya tidak tetap (Variable Cost). Biaya tetap (Fixed Cost) adalah biaya yang relatif tetap jumlahnya, dan terus dikeluarkan walaupun produksi yang diperoleh banyak atau sedikit, jadi besarnya biaya pendapatan ini tidak tergantung besar-kecilnya produksi yang diperoleh. Sedangkan biaya tidak tetap (Variable Cost) adalah biaya yang besar-kecilnya dipengaruhi oleh produksi yang diperoleh. Biaya total usahatani dirumuskan sebagai berikut:

$$
T C=F C-V C
$$

Keterangan: $\mathrm{TC}=$ Total Biaya $($ Total Cost)

FC = Biaya Tetap (Fixed Cost)

$\mathrm{VC}=$ Biaya Variabel (Variable Cost)

\subsubsection{Penerimaan Usahatani}

Penerimaan yang disebut juga dengan pendapatan kotor. Menurut Hadisapoetra (1987) dalam Yuni (2017) merupakan keseluruhan pendapatan yang diperoleh dari semua cabang dan sumber dalam usahatani selama satu tahun, yang dapat diperhitungkan dari hasil penjualan, atau penaksiran kembali. Pendapatan kotor ini didalamnya mencakup: 
1) Jumlah uang yang diterima dari hasil penjualan dengan mengingat akan adanya penerimaan pada permulaan dan akhir bulan.

2) Nilai dari pengeluaran-pengeluaran berupa bahan dari usahatani kepada rumah tangga dan keperluan-keperluan pribadi dari petani dan kepada usaha-usaha yang tidak termasuk usahatani.

3) Nilai dan bahan yang dibayarkan sebagai upah kepada tenaga kerja.

4) Nilai dari hasil bahan uang yang dihasilkan dalam usahatani yang dipergunakan lagi didalam usahatani sendiri sebagai bangunan-bangunan tetap.

5) Tambahan nilai dari persediaan, modal ternak, dan tanaman.

\subsubsection{Pendapatan Usahatani}

Pendapatan usahatani yaitu seluruh pendapatan yang diperolah petani dalam satu kali produksi dikurangi dengan biaya produksi selama proses produksi, sedangkan pendapatan petani yaitu pendapatan yang diperoleh dari kegiatan usahatani ditambah dengan pendapatan yang berasal dari kegiatan diluar usahatani (Soekartawi, 2006). Analsis pendapatan yang diperolah petani dari suatu kegiatan usahataninya memperhitungkan antara nilai produksi dikurangi dengan biaya yang telah dikeluarkan, pendapatan ini akan mendorong petani untuk mengalokasikan dalam berbagai kegunaan seperti: biaya produksi periode selanjutnya, tabungan dan pengeluaran lain untuk memenuhi kebutuhan keluarganya.

Menurut Soekartawi (2006), pendapatan usahatani adalah selisih antara penerimaan dan semua biaya. Jadi, pendapatan dapat dirumuskan sebagai berikut:

$$
P d=T R-T C
$$

Keterangan: $\mathrm{Pd}=$ Pendapatan Usahatani

$\mathrm{TR}=$ Total Penerimaan (Total Revenue)

$\mathrm{TC}=$ Total Biaya (total Cost)

\subsection{Pengambilan Keputusan}

Faktor-faktor yang mempengaruhi pengambilan keputusan antara lain:

\section{1) Faktor Internal}

Pendapatan, dalam kegiatan usahatani aspek pertama yang akan dilihat adalah biaya. Petani dapat menekan biaya untuk memperoleh keuntungan yang lebih besar dengan mengalokasikan input seefisien mungkin untuk memperoleh output yang maksimal. Tujuan utama kegiatan usahatani yaitu untuk memperoleh keuntungan yang maksimal.

Modal, biasanya petani yang memiliki modal banyak akan menginvestasikan usahatani yang dapat memberikan keuntungan yang lebih besar dengan resiko usaha yang dapat diminimalisasikan. Modal ini dapat mempengaruhi petani dalam pengambilan keputusan untuk menentukan usahatani mana yang akan diusahakan. 
Luas lahan, luas areal persawahan yang akan ditanami padi dan budidaya ikan pada musim tertentu. Tanah sawah adalah tanah yang berpetak-petak dan dibatasi pematang (galengan) berfungsi untuk menahan/menyalurkan air dan biasanya ditanami padi sawah, tanpa memandang dari mana diperolehnya ataupun status dari tanah tersebut.

Jumlah tanggungan keluarga, banyaknya anggota keluarga terdiri dari istri, dan anak, serta orang lain yang hidup dalam satu rumah dan makan bersama yang menjadi tanggungan kepala keluarga. Jumlah anggota keluarga dapat mempengaruhi petani atau kepala keluarga dalam pengambilan keputusan melakukan peralihan usahatani yang memberikan keuntungan lebih besar agar kebutuhan keluarganya dapat terpenuhi.

Keputusan ialah suatu pemilihan diantara alternatif-alternatif. Dalam definisi ini mengandung tiga pengertian yaitu: (1) adanya pilihan berdasarkan logika atau pertimbangan, (2) ada beberapa alternatif yang harus dan dipilih salah satu yang terbaik, (3) adanya tujuan yang ingin dicapai, dan keputusan itu makin mendekatkan pada suatu tujuan tertentu.

\section{2) Faktor Eksternal}

Lingkungan ekonomi merupakan kekuatan ekonomi yang berada disekitar seseorang. Menurut Mardikanto et al (1996) dalam Yuni (2017) menyampaikan bahwa kegiatan pertanian tidak dapat terlepas dari kekuatan ekenomi yang berkembang di sekitar masyarakatnya. Kekuatan ekonomi tersebut meliputi: tersedianya dana atau kredit usahatani, tersedia sarana produksi dan peralatan usahatani, perkembangan teknologi pengolahan hasil dan pemasaran hasil.

Lingkungan sosial, petani sebagai pelaksana usahatani (baik sebagai juru tani maupun sebagai pengelola) adalah manusia yang disetiap pengambilan keputusan untuk usahatani tidak selalu dapat dengan bebas dilakukan sendiri, tetapi sangat ditentukan oleh kekuatan-kekuatan yang ada disekelilingnya. Dengan demikian, jika ia ingin melakukan perubahan-perubahan untuk usahataninya, dia juga harus memperhatikan pertimbangan-pertimbangan yang diberikan oleh lingkungan sosialnya (Mardikanto, 1993) dalam Yuni (2017). Menurut Soekartawi (2005) lingkungan sosial yang mempengaruhi perubahanperubahan itu adalah family atau keluarga, tetangga, kelompok sosial dan status sosial.

Memahami perilaku manusia merupakan suatu hal yang sangat sulit karena setiap manusia sebagai individu mempunyai perilaku berbeda-beda. Menurut Wursanto (2005), berdasarkan faktor-faktor yang mempengaruhi perilaku dapat dibedakan menjadi 2 macam yaitu perilaku intern dan ekstern:

1) Perilaku intern yaitu perilaku-perilaku yang dipengaruhi oleh faktor genetika, yaitu segala yang di bawa sejak orang itu lahir sehingga merupakan warisan 
dari orang tuanya. Boleh dikatakan setiap orang mewarisi hal-hal tertentu atau sifat-sifat tertentu dari orang tuanya.

Perilaku ekstern yaitu perilaku yang dipengaruhi oleh faktor dari luar, misalnya faktor lingkungan. Yang dimaksud faktor lingkungan yaitu segenap situasi dan kondisi yang dihadapi sehari-hari oleh seseorang dalam hidupnya. Perilaku seseorang banyak dipengaruhi oleh faktor lingkungan, dan lingkungan yang paling dekat yaitu lingkungan rumah tangga dan masyarakat sekitarnya.

\subsection{Gambaran Umum Usahatani Padi dan Usahatani Ikan}

\subsubsection{Usahatani Padi}

Usahatani padi telah sejak lama dilakukan oleh petani untuk memenuhi kebutuhan hidupnya. Untuk menghasilkan padi yang berkualitas petani mengenal cara bercocok tanam padi yang tepat, dimana masing-masing daerah mempunyai jenis padi yang berbeda-beda yang dapat dilihat dari umur tanaman, banyaknya hasil, mutu beras baik, dan tahan tidaknya terhadap gangguan hama maupun penyakit. Pekerjaan penanaman padi sawah yang harus dilakukan oleh para petani dimulai dengan pembibitan, pengolahan tanah, penanaman, pemeliharaan tanaman, dan pemanenan hasil. Dalam upaya peningkatan produksi padi, pemerintah selalu berupaya untuk mendapatkan jenis-jenis padi yang mempunyai sifat-sifat baik. Jenis-jenis padi disebut dengan "padi jenis unggul" atau "varietas unggul".

\subsubsection{Usahatani Ikan}

Dalam budidaya perikanan terdapat sistem yang tidak dapat dipisahkan yaitu berupa proses antara lain:

1) Input

a) Benih ikan adalah anak ikan dengan ukuran tertentu yang akan digunakan sebagai bahan organik dalam kegiatan pembudidayaan ikan.

b) Pakan ikan merupakan salah satu faktor yang terpenting dalam suatu usaha budidaya perikanan. Pakan akan berpengaruh terhadap pertumbuhan dan kelangsungan hidup ikan yang dibudidayakan.

c) Pestisida merupakan bahan yang digunakan untuk mengendalikan, menolak, atau membasmi organisme pengganggu. Pestisida digunakan untuk membasmi hama dan penyakit yang mengganggu selama proses pembudidayaan ikan berlangsung.

d) Teknologi bertujuan untuk mempermudah pekerja dalam mengerjakan setiap proses dalam budidaya ikan. Peralatan modern sangat mempermudah pekerjaan dibandingkan secara manual. teknologi sebagai input yang sangat menguntungkan demi mencapai produk hasil yang menguntungkan.

e) Tenaga kerja merupakan daya manusia untuk melakukan serangkaian kegiatan yang diperlukan untuk berbagai macam keperluan. Tenaga kerja merupakan faktor penting dalam kegiatan pembudidayaan ikan. 
2) Proses

a) Persiapan Kolam

Kolam dibuat dengan ukuran $300-600 \mathrm{~m}^{2}$ dan sebaiknya dekat dengan sumber air. Sebelum kolam (sawah) di isi air tanahnya diolah terlebih dahulu dengan diberi pupuk an-organik. Selain pemberian pupuk, tanah perlu pengapuran untuk mematikan ikan-ikan liar dalam kolam dan menaikkan $\mathrm{pH}$ tanah.

b) Pendederan Benih

Pendederan benih sebaiknya dilakukan pada pagi atau sore hari saat suhu rendah. Pendederan benih harus disesuaikan dengan luas kolam, karena kolam yang terlalu penuh dengan ikan dapat mengakibatkan bahan makanan alami cepat habis sehingga tidak semua ikan dapat memakan makanannya.

c) Pemeliharaan

Pemeliharaan ikan dilakukan selama $4-6$ bulan atau tergantung ukuran benih yang ditebar dan ukuran ikan yang dipanen. Setelah ikan berumur dua bulan bisa diberi pakan tambahan berupa pellet. Pemberian pellet untuk masa awal. Sedikit demi sedikit untuk membiasakan ikan mengenal makanan barunya. Frekuensi pemberian pakan tambahan adalah $2-3$ kali sehari.

3) Output

Pemanenan ikan dilakukan secara selektif maupun total. Panen selektif dilakukan pada masa pemeliharaan, yaitu dengan memanen ikan yang berukuran besar terlebih dahulu. Panen total dilakukan dengan mengeringkan air kolam.

\subsection{Kerangka Pendekatan Masalah}

Berdasarkan informasi dan pra-survei di Kecamatan Jonggat, didapatkan bahwa petani-petani yang ada di Kecamatan ini mulai melakukan peralihan usahatani. Petani lebih memilih melakukan usahatani ikan daripada usahatani padi yang telah diusahakan terlebih dahulu. Dengan besarnya pendapatan yang diperoleh dari usahatani ikan, membuat petani meninggalkan usahatani padi dan memilih membudidayakan ikan. Namun dalam membudidayakan ikan petani harus mengeluarkan biaya produksi yang lebih besar jika dibandingkan dengan usahatani padi.

Untuk mengkaji analisis pengambilan keputusan petani: kasus peralihan usahatani padi ke usahatani ikan dikembangkan dari penelitian Matakena (2013) dan Kiazan (2014). Dalam penelitian terdahulu ini, telah dikemukakan beberapa faktor yang mempengaruhi peralihan usahatani seperti pengalaman berusahatani, pendapatan, pengaruh petani lain. Dari beberapa faktor dalam penelitian ini yaitu faktor internal (pengalaman berusahatani, pendapatan, kondisi lahan yang dimiliki dan pengetahuan) dengan Faktor eksternal dimana akan didapatkan setelah 
melakukan penelitian dilapangan. Ini dimaksudkan untuk memperoleh informasi yang lebih menunjukkan keadaan petani yang sebenarnya dilapangan.

\section{METODOLOGI PENELITIAN}

Penelitian ini dilakukan pada bulan Februari 2017 - Maret 2017 pada petani padi dan petani ikan di desa Bunkate. Data primer dalam penelitian ini diperoleh melalui metode survey dan wawancara, yaitu dengan petani padi dan petani ikan yang terdiri dari 44 petani responden yaitu 22 orang petani padi dan 22 orang petani ikan. Adapun data sekunder dalam penelitian ini diperoleh dari berbagai literature, seperti buku, artikel ilmiah, internet, dan dokumen-dokumen pemerintah. Teknik pengambilan sampel yang digunakan adalah Assidental Sampling. Data yang diperoleh dianalisis menggunkan analisis deskriptif untuk mengetahui tingkat hubungan antara pendapatan, modal, luas lahan, jumlah tanggungan keluarga dan resiko usahatani dengan pengambilan keputusan peralihan usahatani. Analisis selanjutnya yang digunakan adalah analisis uji t.

\section{HASIL DAN PEMBAHASAN}

\subsection{Gambaran Umum Daerah Penelitian}

Gambaran umum daerah penelitian ini meliputi letak geografis dan keadaan wilayah dan iklim dan jumlah penduduk dan kepadatan penduduk.

\subsection{Karakteristik Responden}

Karakteristik responden dalam penelitian ini meliputi: umur, tingkat pendidikan, jumlah tanggungan keluarga, pengalaman berusahatani, luas lahan, kondisi pengairan dan kondisi lahan.

Umur Responden. Rata-rata umur petani padi adalah 45 tahun sedangkan rata-rata umur petani ikan adalah 40 tahun. Rata-rata umur pada kedua usahatani tersebut berada pada usia produktif, sehingga memungkinkan untuk menyerap inovasi yang baru untuk memajukan usahataninya.

Tingkat Pendidikan. Tingkat pendidikan petani responden untuk petani padi sebanyak $31,81 \%$ tamat $\mathrm{SD}$, sedangkan tingkat pendidikan petani ikan sebanyajk 45,45\% tamat SMA. Tingkat pendidikan yang tinggi akan berpengaruh pada kemampuan petani untuk mengelola usahataninya, mengadopsi teknologi dan inovasi baru serta penerapannya pada kegiatan usahatani. Menurut Soekartawi (2002) masyarakat dengan tingkat pendidikan SD ke bawah masih tergolong tingkat pendidikan rendah, beberapa petani dengan tingkat pendidikan diatas SD lebih berpengaruh dalam hal perubahan dan penyerapan teknologi, dan dapat mempengaruhi petani lain yang memiliki pendidikan rendah.

Tanggungan Keluarga. Rata-rata jumlah tanggungan keluarga petani padi yaitu 4 orang atau 63,64\%, sedangkan petani ikan yaitu 77,27\% atau 3 orang. Jumlah anggota keluarga akan berpengaruh terhadap perekonomian 
keluarga,semakin banyak jumlah anggota keluarga maka akan meningkatkan pula kebutuhan keluarga, hal ini akan membuat biaya hidup meningkat.

Pengalaman Berushatani. Pengalaman usahatani petani padi lebih lama dibandingkan petani ikan. Penglaman petani ikan lebih sedikit dibandingkan dengan pengalaman petani padi disebabkan oleh jenis kegiatan usahatani ikan belum lama diusahakan oleh petani responden berkisar antara 5-6 tahun. Sedangkan untuk usahatani padi, rata-rata pengalaman usahataninya $10-29$ tahun.

Luas Lahan. rata-rata luas lahan petani padi yaitu 0,38 ha, sedangkan rata-rata luas lahan petani ikan yaitu 0,17 ha. Keadaan lahan serta luas lahan akan mempengaruhi produksi dan penggunaan tenaga kerja dari suatu usahatani.

\subsection{Biaya dan Pendapatan Usahatani Padi dan Usahatani Ikan}

\subsubsection{Biaya Produksi}

Biaya produksi merupakan seluruh pengeluaran untuk membiayai proses produksi dalam usahatani.

\section{1) Biaya Variabel}

Biaya variabel adalah biaya yang besar kecilnya dipengaruhi oleh jumlah produksi.

a) Biaya Sarana Produksi dan Tenaga Kerja

Tabel 2. Biaya Sarana Produksi dan Tenaga kerja Usahatani Padi dan usahatani ikan di Desa Bunkate Kecamatan Jonggat, 2017.

\begin{tabular}{lccrr}
\hline \multirow{2}{*}{ Jenis Biaya } & \multicolumn{2}{c}{ Usahatani Padi } & \multicolumn{2}{c}{ Ushatani Ikan } \\
\cline { 2 - 5 } & $(\mathrm{Rp} / \mathrm{LLG})$ & $(\mathrm{Rp} / \mathrm{Ha})$ & $(\mathrm{Rp} / \mathrm{LLG})$ & \multicolumn{1}{c}{$(\mathrm{Rp} / \mathrm{Ha})$} \\
\hline Saprodi & 1.210 .049 & 3.278 .107 & 2.895 .520 & 16.675 .772 \\
Tenaga Kerja & 2.431 .592 & 6.330 .767 & 757.955 & 4.361 .184 \\
Total & 3.641 .641 & 9.608 .874 & 3.653 .205 & 21.036 .906 \\
\hline
\end{tabular}

Sumber: Data Primer Diolah (2018).

Biaya sarana produksi yang dikeluarkan oleh petani dalam usahatani padi dan usahatani ikan terdiri atas pembelian benih/bibit, pupuk, dan obat-obatan. Tingkat penggunaan sarana produksi fisik dan besarnya nilai biaya yang dikeluarkan pada usahatani padi dihitung rata-rata per luas lahan garapan dan rata-rata per hektar sebesar Rp. 1.210.049/LLG dengan 3.278.107/ha. Sedangkan rata-rata biaya sarana produksi ikan yaitu Rp. 2.895.520/LLG dengan Rp. 16.675.772/ha.

Rata-rata biaya tenaga kerja yang dikeluarkan oleh petani padi adalah $\mathrm{Rp}$. 2.431.592/LLG dengan Rp. 6.330.767/ha. Sedangkan pada usahatani ikan sebesar Rp. 757.955/LLG dengan Rp. 4.361.184/ha. Besarnya tenaga kerja yang dikeluarkan pada usahatani padi karena banyaknya kegiatan usahatani yang membutuhkan tenaga kerja dan curahan waktu kerja yang cukup lama. 


\section{2) Biaya Tetap}

Tabel 3. Biaya Tetap dan Lain-lain Pada Usahatani Padi dan Usahatani Ikan di Desa Bunkate Kecamatan Jonggat, 2017.

\begin{tabular}{llrrrr}
\hline \multirow{2}{*}{ No } & \multirow{2}{*}{ Jenis Biaya } & \multicolumn{2}{c}{ Usahatani Padi } & \multicolumn{2}{c}{ Usahatani Ikan } \\
\cline { 3 - 6 } & & $(\mathrm{Rp} / \mathrm{LLG})$ & $(\mathrm{Rp} / \mathrm{Ha})$ & $(\mathrm{Rp} / \mathrm{LLG})$ & $\mathrm{Rp} / \mathrm{Ha})$ \\
\hline 1 & Penyusutan & 354.811 & 923.767 & 423.867 & 2.441 .121 \\
& Alat & & & & \\
2 & Pajak Tanah & 164.659 & 428.698 & 39.068 & 225.000 \\
& Total & 519.470 & 1.352 .465 & 462.935 & 2.66 .121 \\
\hline
\end{tabular}

Sumber: Data Primer Diolah (2018).

Biaya penyusutan peralatan usahatani ikan memiliki biaya tetap lebih besar yaitu Rp. 2.441.12/ha per musim tanam, sedangkan usahatani padi memiliki biaya tetap sebesar Rp. 923.767/ha per musim tanam. Pada usahatani padi dan usahatani ikan, komponen biaya terbesar yaitu biaya penyusutan alat. Besarnya biaya penyustan alat karena kedua usahatani ini, menggunakan alat pertanian yang cukup banyak sementara umur ekonomis dari barang pertanian tidak terlalu lama.

Besarnya biaya pajak tanah pada masing-masing usahatani tersebut yaitu Rp. 428.698/ha per musim tanam untuk usahatani padi, sedangkan untuk usahatani ikan yaitu Rp. 225.000/ha per musim tanam. Biaya pajak dilokasi penelitian ditentukan oleh luas lahan yang dimiliki oleh petani.

\subsubsection{Produksi dan Pendapatan Usahatani Padi dan Usahatani Ikan}

Rata-rata total biaya pada usahatani ikan adalah sebesar Rp. 23.707.077/ha, lebih besar dibandingkan dengan usahatani padi yang hanya Rp. 10.808.266/ha. Usahatani ikan memiliki pendapatan sebesar Rp. 129.172.923/ha, lebih besar dari pendapatan padi yaitu Rp. 13.316.234/ha.

Tabel 4. Produksi, Harga, Nilai Produksi, Biaya Produksi, dan Pendapatan Usahatani Padi dan Usahatani Ikan di Desa Bunkate Kecamatan Jonggat, 2017.

\begin{tabular}{cllrr}
\hline No. & \multicolumn{1}{c}{ Uraian } & Satuan Fisik & Padi (Nilai/Ha) & Ikan (Nilai/ha) \\
\hline 1 & Produksi & $\mathrm{Kg}$ & 5.361 & 9.555 \\
2 & Harga & $\mathrm{Rp} / \mathrm{Kg}$ & 4.500 & 16.000 \\
3 & Nilai Produksi & $\mathrm{Rp}$ & 24.124 .500 & 152.052 .923 \\
4 & Biaya Produksi & $\mathrm{Rp}$ & 10.808 .266 & 23.707 .077 \\
5 & Pendapatan & $\mathrm{Rp}$ & 13.316 .234 & 129.172 .923 \\
6 & R/C Ratio & $\%$ & 2,23 & 6,42 \\
\hline
\end{tabular}

Sumber: Data Primer Diolah (2018).

Tabel 4 menunjukkan bahwa $R / C$ ratio pada usahatani ikan yaitu $6,42 \%$ yang artinya setiap penambahan biaya input sebesar Rp. 1,00 akan meningkatkan pendapatan sebesar Rp. 6,42, sedangkan $R / C$ ratio pada usahatani padi yaitu $2,23 \%$ yang artinya setiap penambahan biaya input sebesar Rp. 1,00 akan meningkatkan pendapatan sebesar Rp. 2,23. Karena nilai kedua usahatani lebih 
dari satu maka dapat disimpulkan bahwa usahatani padi dan usahatani ikan layak untuk diusahakan.

\subsection{Faktor-faktor yang mempengaruhi peralihan usahatani padi ke usahatani ikan}

Terdapat beberapa faktor yang mempengaruhi peralihan usahatani dari usahatani padi ke usahatani ikan yang terdiri dari faktor internal dan faktor eksternal. Hasil olah data regresi model logit terhadap variabel yang mempengaruhi petani melakukan peralihan usahatani disajikan pada tabel berikut.

Tabel 5. Hasil olah faktor yang mempengaruhi peralihan usahatani

\begin{tabular}{lrrrc}
\hline Variabel & \multicolumn{1}{c}{ B } & P-Value & Exp $(\mathrm{B})$ & Keterangan \\
\hline Pendapatan & $-3,114$ & 0,057 & 0,680 & S* \\
Modal & $-0,004$ & 0,232 & 0,996 & TS* \\
Luas Lahan & 2,864 & 0.565 & 17,523 & TS* $^{*}$ \\
Jumlah Tanggungan & 0,919 & 0,076 & 2,506 & TS $^{*}$ \\
Resiko Usahatani & 0,037 & 0.143 & 1,037 & TS $^{*}$ \\
\hline
\end{tabular}

Sumber: Data Primer Diolah (2018).

Keterangan: * Variabel tersebut nyata pada taraf kepercayaan $95 \%$

Variabel pendapatan ikan berpengaruh secara signifikan terhadap pengambilan keputusan petani dalam melakukan peralihan usahatani padi ke usahatani ikan pada taraf kepercayaan 95\% dengan arah yang positif. Koefisien odd ratio pada kolom $\operatorname{Exp}(\mathrm{B})$ untuk pendapatan sebesar 0,680. Karena koefisien $\mathrm{B}$ bertanda negatif dapat diartikan bahwa kemungkinan beralih dari usahatani padi ke usahatani ikan dengan tetap berusahatani padi rendah dengan faktor 0,680 kali dengan asumsi variabel modal, luas lahan, jumlah tanggungan keluarga dan resiko usahatani tetap. Menurut Soekartawi (2002) seorang petani sebelum mengelola usahataninya akan mempertimbangkan antara biaya dan pendapatan, dengan mempertimbangkan sumberdaya yang ada secara efektif dan efisien, guna memperoleh keuntungan.

Modal tidak berpengaruh secara signifikan terhadap pengambilan keputusan peralihan usahatani padi ke usahatani ikan pada taraf kepercayaan 95\% dengan arah yang positif. Koefisien odd ratio pada kolom $\operatorname{Exp(B)}$ untuk modal sebesar 0,996. Karena nilai koefisien B bertanda negatif dapat diartikan bahwa jika modal naik 1 unit (1 juta) menyebabkan penurunan peluang petani melakukan peralihan dari usahatani padi ke usahatani ikan dengan faktor 0,004 kali, dengan asumsi variabel pendapatan, luas lahan, jumlah tanggungan keluarga dan resiko usahatani tetap.

Luas lahan tidak berpengaruh secara signifikan terhadap pengambilan keputusan petani padi melakukan peralihan ke usahatani ikan pada taraf 
kepercayaan 95\% dengan arah yang positif. Koefisien odd ratio pada kolom $\operatorname{Exp}(B)$ untuk modal sebesar 17,523. Karena nilai koefisien B bertanda positif dapat diartikan bahwa setiap penambahan luas lahan sebesar 1 unit (1 ha) akan menyebabkan penurunan peluang petani melakukan peralihan usahatani padi ke usahatani ikan dengan faktor 17.523 kali, dengan asumsi pendapatan, modal, jumlah tanggungan keluarga dan resiko usahatani tetap.

Jumlah tanggungan keluarga tidak berpengaruh secara signifikan terhadap pengambilan keputusan petani padi melakukan peralihan ke usahatani ikan pada taraf kepercayaan $95 \%$ dengan arah yang positif. Koefisien odd ratio pada kolom $\operatorname{Exp}(B)$ untuk modal sebesar 2,506. Karena nilai koefisien B bertanda positif dapat diartikan bahwa setiap penambahan jumlah tanggungan keluarga sebesar 1 unit (1 orang) akan menyebabkan penurunan peluang petani dalam melakukan peralihan usahatani padi ke usahatani ikan dengan faktor 2.506 kali, dengan asumsi variabel pendapatan, modal, luas lahan dan resiko usahatani tetap.

Resiko usahatani tidak berpengaruh secara signifikan terhadap pengambilan keputusan petani padi melakukan peralihan ke usahatani ikan pada taraf kepercayaan $95 \%$ dengan arah yang positif. Koefisien odd ratio pada kolom Exp(B) untuk modal sebesar 1,037. Karena nilai koefisien B bertanda positif dapat diartikan bahwa setiap penambahan resiko usahatani sebesar 1 unit $(10 \%)$ akan menyebabkan penurunan peluang petani dalam melakukan peralihan usahatani padi ke usahatani ikan dengan faktor $1.037 \mathrm{kali}$, dengan asumsi variabel pendapatan, modal, luas lahan dan jumlah tanggungan keluarga tetap.

\subsection{Perbandingan Pendapatan Usahatani Padi dan Usahatani Ikan}

Tabel 6. Analisis Komparasi Pendapatan Per Hektar Usahatani Padi dan Usahatani Ikan di Desa Bunkate Kecamatan Jonggat, 2017.

\begin{tabular}{|c|c|c|c|c|}
\hline \multirow{2}{*}{ Uraian } & \multicolumn{2}{|c|}{ Nilai } & \multirow{2}{*}{$\begin{array}{c}\mathrm{T} \text {-hitung } \\
(\alpha 0,05)\end{array}$} & \multirow{2}{*}{$\begin{array}{c}\mathrm{T} \text {-tabel } \\
(\alpha 0,05)\end{array}$} \\
\hline & Usahatani Padi & Usahatani Ikan & & \\
\hline $\begin{array}{l}\text { Pendapatan } \\
\text { (Rp/Ha) }\end{array}$ & 13.316 .234 & 129.172 .923 & 5,133 & 2,018 \\
\hline
\end{tabular}

Sumber: Data Primer Diolah (2018).

Berdasarkan tabel 6, diketahui hasil uji t menunjukkan bahwa nilai thitung lebih besar dibandingkan nilai tabel yakni $t_{\text {hitung }}$ sebesar 5,133 sedangkan nilai tabel sebesar 2,018. Hal tersebut berarti bahwa pendapatan usahatani ikan lebih besar dibandingkan pendapatan usahatani padi. 


\section{BAB V \\ KESIMPULAN DAN SARAN}

\subsection{Kesimpulan}

Dari hasil penelitian tentang analisis pengambilan keputusan petani: kasus peralihan usahatani padi ke usahatani ikan di Desa Bunkate Kecamatan Jonggat, kesimpulan yang dapat diambil anatara lain sebagai berikut:

1. Faktor yang mempengaruhi peralihan usahatani padi ke usahatani ikan adalah pendapatan.

2. Nilai $\mathrm{R} / \mathrm{C}$ ratio pada usahatani padi lebih kecil dibandingkan dengan nilai $\mathrm{R} / \mathrm{C}$ ratio usahatani ikan. Biaya produksi dalam usahatani padi adalah Rp. 10.808.266/ha, dengan penerimaan Rp. 24.124.500/ha, sehingga pendapatan yang diperoleh adalah Rp. 13.316.234/ha. Biaya produksi usahatani ikan yaitu Rp. 23.707.077/ha, dengan penerimaan Rp. 152.052.923/ha, sehingga pendapatan yang diperoleh adalah Rp. 129.172.923/ha.

\subsection{Saran}

Berdasarkan hasil penelitian dan kesimpulan, maka dapat diajukan saran yaitu:

1. Bagi petani, petani dapat memilih kedua jenis usahatani (usahatani padi dan usahatani ikan) karena kedua usahatani tersebut layak untuk diusahakan secara finansial.

2. Pemerintah, khususnya PPL (Penyuluh Pertanian Lapangan) diharapkan lebih aktif, kreatif dan inovatif lagi dalam melakukan kegiatan penyuluhan dan pembinaan serta memberikan inovasi-inovasi baru yang sesuai dengan kondisi lahan petani dengan harapan mampu memberikan dan menawarkan solusi dari berbagai macam masalah yang dihadapi oleh petani.

3. Dalam penelitian ini belum di ketahui apakah biaya usahatani mempengaruhi peralihan dari usahatani padi ke usahatani ikan, oleh karena itu hal tersebut dapat menjadi aspek baru yang perlu diteliti.

\section{DAFTAR PUSTAKA}

Badan Pusat Statistika Kabupaten Lombok Tengah 2012, Dalam Angka 2012, Badan Pusat Statistik Kabupaten Lombok Tengah.

Badan Pusat Statistika Kabupaten Lombok Tengah 2017, Dalam Angka 2017, Badan Pusat Statistik Kabupaten Lombok Tengah.

Badan Pusat Statistika Kecamatan Jonggat 2016, Dalam Angka 2016, Badan Pusat Statistik Nusa Kabupaten Lombok Tengah.

Badan Pusat Statistika Nusa Tenggara Barat 2017, Lombok Tengah Dalam Angka 2017, Badan Pusat Statistik Nusa Tenggara Barat. 
Hadisapoetra, Soedarsono, 1987. Biaya dan Pendapatan Usahatani. Fakultas Pertanian Universitas Gajah Mada. Yogyakarta.

Kaizan, Arifin B., Santoso H,. 2014. Kelayakan Finansial dan Nilai Ekonomi Lahan (Land Rent) pada Penggantian Usahatani Kopi Menjadi Karet di Kabupaten Way Kanan Provinsi lampung. J11a. 2 No. 4 www.digilib.unila.ac.id. [Diakses 19 januari 2018].

Matakena, S. 2013. Faktor-faktor yang Mempengaruhi Peralihan Usahatani Padi Ke Usahatani Jeruk Manis (Studi Kasus Pada Komunitas Petani Jeruk Manis di Kampong Wadio Distrik Barat Kabupaten Nabire). Jurnal. Fakultas Pertanian dan perternakan Universitas Satya Wiyata Mandala Nabire-Papua. Http://www.ejournal.unpatti.ac.id. (Diakses 19 Januari 2018).

Mubyarto, 1989. Pengantar Ekonomi Pertanian. LP3ES. Jakarta

Soekartawi, 2002. Analisis usahatani. Universitas Indonesia (UI-Press). Jakarta.

Soekartawi, 2005. Prinsip Dasar Komunitas Pertanian. (UI-Press). Jakarta.

Soekartawi, 2006. Analsis Usahatani. Penerbit Universitas Indonesia. Jakarta.

V.M. Sidauruk, Rahmanta Ginting, Emalisa, 2015. Analisis Tingkat Adopsi Petani Terhadap Teknologi Budidaya Jagung dan Hubungannya Dengan Faktor Sosial Ekonomi (Studi Kasus: Kecamatan Lumban Julu, Kabupaten Toba Samosir). Fakultas Pertanian dan Perternakan Universitas Satya Wiyata Mandala Nabire-Papua. https://jurnal.usu.ac.id. [Diakses 2 April 2018].

Wursanto, 2005. Dasar-dasar ilmu Organisasi. Andi Offset. Yogyakarta.

Yuni A. 2017. Faktor-faktor yang Mempengaruhi Peralihan Usahatani Kacang Hijau Ke Usahatani Jagung di Kecamatan Empang Kabupaten Sumbawa. Fakultas Pertanian Universitas Mataram. 